\title{
Heterocyclic Synthesis via Enaminones: Synthesis and Molecular Docking Studies of Some Novel Heterocyclic Compounds Containing Sulfonamide Moiety
}

\author{
Ahmed Abd El-Hameed Hassan ${ }^{1,2}$ \\ ${ }^{1}$ Chemistry Department, Faculty of Science, Al-Azhar University, Nasr City, Egypt \\ ${ }^{2}$ Chemistry Department, Faculty of Medicine, Jazan University, Jazan, KSA \\ Email: ahmed hassan7979@hotmail.com
}

Received 25 January 2014; revised 28 February 2014; accepted 10 March 2014

Copyright (C) 2014 by authors and Scientific Research Publishing Inc.

This work is licensed under the Creative Commons Attribution International License (CC BY). http://creativecommons.org/licenses/by/4.0/

(c) (i) Open Access

\begin{abstract}
4-Acetyl-N, N-diethylbenzenesulfonamide (1) was condensed with dimethylformamide dimethylacetal (DMF-DMA) to yield the enaminone, which reacts readily with different reagents to give the corresponding pyrazoles, triazolopyrimidine, imidazopyridine, pyrimidopyrimidine, pyrazolopyrimidine, benzofuran, pyranone, pyridine, pyrimidine and pyrazolopyridazine derivatives. These compounds were designed to comply with the general features of sulfonamide pharmacophore which act as Cyclooxygenase (COX-2) inhibitors. Virtual screening using molecular docking studies of the synthesized compounds was performed by (MOE), the molecular docking results indicate that, some synthesized compounds suitable inhibitor against (COX-2) with further modification.
\end{abstract}

\section{Keywords}

DMF-DMA; Pyrazoles; Benzofuran; Pyranone; Pyridine; Pyrimidine; Doking

\section{Introduction}

Enaminones are polydentate reagents that have been utilized extensively in this decade as building blocks in organic synthesis [1]-[6]. Also sulfonamides possess many types of biological activities and representatives of this class of pharmacological agents are widely used in clinic as antibacterial [7], antithyroid, diuretic, hypoglycaemic and anti-cancer [8]-[12]. Moreover, non-steroidal anti-inflammatory drugs (NSAIDs) are widely employed in musculoskeletal disease, as well as their anti -inflammatory properties [13]. After widely evaluation, NSAIDs 
are efficacy in different clinical setting, and act as a COX inhibitor (COX-1 and COX-2) through inhibiting the production of prostaglandins (PGs) [14]-[16]. Diclofenac is a one from famous available members of this drug's class under current clinical usage [17], and suffers from a common toxicity of gastrointestinal drawback, due to inhibition non-selectivity of cyclooxygenase enzyme [18]-[20], also, its display anti-microbial [21]-[23], ulcerogenic, analgesic, anti-inflammatory, lipid peroxidation [24] [25], antitumor [26] and inhibitor formation of transthyretin amyloid fibril properties [27]. In this paper, we have reported a variety of syntheses of heteroaromatics developed using functionally substituted enaminones as readily obtainable building blocks possessing multiple electrophilic and nucleophilic moieties.

\section{Material and Methods}

\subsection{Experimental}

All melting points, antioxidant and anticancer activities are uncorrected. IR spectra $(\mathrm{KBr})$ were recorded on FT-IR 5300 spectrometer and Perkin Elmer spectrum RXIFT-IR system $\left(v, \mathrm{~cm}^{-1}\right)$. The ${ }^{1} \mathrm{H}$-NMR spectra were recorded in (DMSO-d6) at $300 \mathrm{MHz}$ on a Varian Mercury VX-300 NMR spectrometer ( $\delta$, ppm) using TMS as an internal standard. ${ }^{13} \mathrm{C}-\mathrm{NMR}$ spectra were recorded on Varian Mercury VX 300 NMR using DMSO-d6 as solvent and TMS as an internal standard. Mass spectrum was obtained on GC MS-QP 1000 EX mass spectrometer at $70 \mathrm{eV}$. Elemental analyses were carried out by the Microanalytical Research Center, Faculty of Science, Cairo University and Al-Azhar University.

(E)-4-(3-(Dimethylamino)acryloyl)-N, N-diethylbenze-nesulfonamide (2).

A mixture of 4-acetyl-N,N-diethylbenzenesulfonamide $1(0.01 \mathrm{~mol})$ and DMF-DMA (0.012 mol) in dry xylene $(50 \mathrm{ml})$ was heated under reflux for $4 \mathrm{hr}$. The separated solid was filtered off, washed with ethanol and recrystallized to give (2).Color: bright yellow; Yield: 83\%; M.p.: $96^{\circ} \mathrm{C}-98^{\circ} \mathrm{C}$; FT-IR $\left(\mathrm{KBr}, v, \mathrm{~cm}^{-1}\right): 3100$ (CH-arom.), 2920 (CH-aliph.), 1646 (CO), 1336, 1154 ( $\left.\mathrm{SO}_{2}\right)$; ${ }^{1} \mathrm{HNMR}$ (300 MHz, DMSO- $d_{6}, \delta$, ppm): 1.01 (t, $\left.6 \mathrm{H}, \mathrm{CH}_{3}-\mathrm{CH}_{2}\right), 2.90$ and $3.13\left(2 \mathrm{~s}, 6 \mathrm{H}, \mathrm{N}\left(\mathrm{CH}_{3}\right)_{2}\right), 3.29\left(\mathrm{q}, 4 \mathrm{H}, \mathrm{CH}_{2}-\mathrm{CH}_{3}\right), 5.79$ and $7.72(\mathrm{dd}, 2 \mathrm{H}$, olefinic $\mathrm{CH}=$ $\mathrm{CH} ; \mathrm{J}=12.25 \mathrm{~Hz}$ ), 7.78 and 8.02 (dd, $4 \mathrm{H}, \mathrm{AB}-\mathrm{ArH} ; \mathrm{J}=8.4 \mathrm{~Hz}$ ); ${ }^{13} \mathrm{C}-\mathrm{NMR}(300 \mathrm{MHz}$, DMSO-d 6 , $\delta$, ppm):14.6, 40.3, 42.3, 91.4, 127.1, 128.5, 141.8, 144.1, 155.4, 184.7; Anal. Calcd. for $\mathrm{C}_{15} \mathrm{H}_{22} \mathrm{~N}_{2} \mathrm{O}_{3} \mathrm{~S}$ : C, 58.04; $\mathrm{H}, 7.14 ; \mathrm{N}$, 9.02. Found: C, $57.91 ; \mathrm{H}, 7.03$; N, 8.90.

\section{4-(1-Acetyl-1H-pyrazol-3-yl)-N, N-diethylbenzenesulfonamide (4).}

A mixture of enaminone $2(0.01 \mathrm{~mol})$ and hydrazine hydrate $(0.01 \mathrm{~mol})$ in ethanol/acetic acid $(30 \mathrm{ml})(1: 1)$ was heated under reflux for 5 hrs. During the reflux period, a crystalline solid was separated. The separated solid was filtered off, washed with ethanol to give 4. Color: White; Yield: $73 \%$; M.p.: $187^{\circ} \mathrm{C}-189^{\circ} \mathrm{C}$; FT-IR $(\mathrm{KBr}, v$, $\mathrm{cm}^{-1}$ ): 1684 (CO), 1380, $1152\left(\mathrm{SO}_{2}\right) ;{ }^{1} \mathrm{HNMR}\left(300 \mathrm{MHz}, \mathrm{DMSO}-\mathrm{d}_{6}, \delta\right.$, ppm): 1.02 (t, $\left.6 \mathrm{H}, \mathrm{CH}_{3}-\mathrm{CH}_{2}\right), 1.79$ (s, $3 \mathrm{H}, \mathrm{CH}_{3}$ ), 3.31 (q, 4H, $\mathrm{CH}_{2}-\mathrm{CH}_{3}$ ), 6.81 and 8.85 (dd, 2H,H- 4, H-5 pyrazole), 7.77 and 7.98 (dd, 4H, AB-ArH; J = 8.4 Hz); MS (EI, $m / z(\%)$ ): $321\left(\mathrm{M}^{+}\right)(8.6), 77$ (100); Anal. calcd. for $\mathrm{C}_{15} \mathrm{H}_{19} \mathrm{~N}_{3} \mathrm{O}_{3} \mathrm{~S}: \mathrm{C}, 56.06 ; \mathrm{H}, 5.96 ; \mathrm{N}, 13.07$. Found: C, 55.92; H, 5.80; N, 12.93.

\section{4-(1-(2-Cyanoacetyl)-1H-pyrazol-3-yl)-N,N-diethylbenzenesulfonamide (5).}

A mixture of enaminone $2(0.01 \mathrm{~mol})$ and cyanoacetohydrazide $(0.01 \mathrm{~mol})$ in ethanol/acetic acid $(30 \mathrm{ml})(1: 1)$ was heated under reflux for 3hrs. During the reflux period, a crystalline solid was separated. The separated solid was filtered off, washed with ethanol to give 5. Color: yellow; Yield: $68 \%$; M.p.: $215^{\circ} \mathrm{C}-217^{\circ} \mathrm{C}$; FT-IR $(\mathrm{KBr}, v$, $\mathrm{cm}^{-1}$ ): 2224 (CN), 1638 (CO), 1334, $1156\left(\mathrm{SO}_{2}\right) ;{ }^{1} \mathrm{HNMR}$ (300 MHz, DMSO-d 6 , $\left.\delta, \mathrm{ppm}\right): 1.03$ (t, $6 \mathrm{H}, \underline{\mathrm{CH}}_{3^{-}}$ $\mathrm{CH}_{2}$ ), 3.22 (q, $4 \mathrm{H}, \mathrm{CH}_{2}-\mathrm{CH}_{3}$ ), 3.31 (s, $2 \mathrm{H}, \mathrm{CH}_{2}$ ), 7.47 and 8.23 (dd, 2H,H-4, H-5 pyrazole), 7.96 and 8.30 (dd, $4 \mathrm{H}, \mathrm{AB}-\mathrm{ArH} ; \mathrm{J}=8.4 \mathrm{~Hz}$ ); Anal. calcd. for $\mathrm{C}_{16} \mathrm{H}_{18} \mathrm{~N}_{4} \mathrm{O}_{3} \mathrm{~S}$ : C, 55.48; H, 5.24; N, 16.17. Found: C, 55.33; H, 5.11; N, 16.01 .

4-(4-Cyanobenzo[4,5]imidazo[1,2-a]pyridin-1-yl)-N,N-diethylbenzenesulfonamide (7).

A mixture of enaminone $2(0.01 \mathrm{~mol})$ and $1 \mathrm{H}$-benzo-imidazole-2-ylacetonitrile $(0.01 \mathrm{~mol})$ in glacial acetic acid $(30 \mathrm{ml})$ was refluxed for $2 \mathrm{hr}$. The solid product which obtained after cooling was collected by filtration and recrystallized to give 7. Color: yellowish white; Yield: 65\%; M.p.: $332-334^{\circ} \mathrm{C}$; FT-IR $\left(\mathrm{KBr}, v, \mathrm{~cm}^{-1}\right): 2986$ (CH-aliph.), 2228 (CN), 1334, 1156 (SO $\left.{ }_{2}\right) ;{ }^{1} \mathrm{HNMR}$ (300 MHz, DMSO-d $d_{6}, \delta$, ppm): 1.08 (t, $6 \mathrm{H}, \mathrm{CH}_{3}-\mathrm{CH}_{2}$ ), 3.38 (q, 4H, $\mathrm{CH}_{2}-\mathrm{CH}_{3}$ ), $7.02-8.33$ (m, 10H, ArH + 2H pyridine ring); MS, m/z (\%): $404\left(\mathrm{M}^{+}\right)(20.4), 268$ (100); ${ }^{13} \mathrm{C}-\mathrm{NMR}$ (300 MHz, DMSO-d 6 , $\delta$, ppm): 14.3, 40.3, 103.2, 112.3, 114.7, 120.5, 122.0, 126.6, 128.0, 129.4, 130.4, 137.1, 138.1, 144.8, 160.9; Anal. calcd. for $\mathrm{C}_{22} \mathrm{H}_{20} \mathrm{~N}_{4} \mathrm{O}_{2} \mathrm{~S}$ : C, 65.33; H, 4.98; N, 13.85. Found: C, 65.20; H, 4.86; N, 13.71 . 
4-(8-Oxo-6-thioxo-7,8-dihydro-6H-pyrimido[1,6-a]pyrimidin-4-yl)-N,N-diethylbenzenesulfonamide (8).

A mixture of enaminone $2(0.01 \mathrm{~mol})$ and 6 -amino-2-thiouracil $(0.01 \mathrm{~mol})$ in glacial acetic acid $(40 \mathrm{ml})$ was refluxed for $3 \mathrm{~h}$. The solvent was removed by distillation under reduced pressure and the resulting solution was left to cool. The solid precipitate was collected by filtration; Color: yellow; Yield: $69 \%$; M.p.: $315^{\circ} \mathrm{C}-317^{\circ} \mathrm{C}$; FT-IR (KBr, v, cm ${ }^{-1}$ ): $3110(\mathrm{NH}), 2978$ (CH-aliph.), 1686 (CO), 1336, $1158\left(\mathrm{SO}_{2}\right) ;{ }^{1} \mathrm{HNMR}(300 \mathrm{MHz}$, DMSO- $d_{6}, \delta$, ppm): 1.02 (t, $\left.6 \mathrm{H}, \mathrm{CH}_{3}-\mathrm{CH}_{2}\right), 1.90$ (s, $\left.1 \mathrm{H}, \mathrm{SH}\right), 3.18$ (q, 4H, $\left.\mathrm{CH}_{2}-\mathrm{CH}_{3}\right), 7.93-8.97$ (m, 7H, $\mathrm{ArH}+$ pyrimidine ring); MS (EI, $\mathrm{m} / \mathrm{z}(\%)): 390\left(\mathrm{M}^{+}\right)(29.2), 254$ (83.3), 56 (100); Anal. calcd. for $\mathrm{C}_{17} \mathrm{H}_{18} \mathrm{~N}_{4} \mathrm{O}_{3} \mathrm{~S}_{2}$ : C, 52.29; H, 4.65; N, 14.35. Found: C, 52.14; H, 4.51; N, 14.22.

4-([1,2,4]Triazolo[4,3-a]pyrimidin-5-yl)-N,N-diethylbenzenesulfonamide (10).

A mixture of enaminone $2(0.01 \mathrm{~mol})$ and 3-amino- $1 \mathrm{H}-1,2,4$-triazole $(0.01 \mathrm{~mol})$ in acetic acid $(30 \mathrm{ml})$ was refluxed for $5 \mathrm{hr}$. During the reflux period, a crystalline solid was separated. The separated solid was filtered off, washed with ethanol and recrystallized to give the compound 10. Color: yellow; Yield: $73 \%$; M.p.: $238^{\circ} \mathrm{C}-$ 240 ${ }^{\circ} \mathrm{C}$; FT-IR (KBr, $\left.v, \mathrm{~cm}^{-1}\right)$ : 2980 (CH-aliph.), 1336, $1160\left(\mathrm{SO}_{2}\right) ;{ }^{1} \mathrm{HNMR}\left(300 \mathrm{MHz}\right.$, DMSO-d $d_{6}, \delta$, ppm): 1.05 (t, $6 \mathrm{H}, \mathrm{CH}_{3}-\mathrm{CH}_{2}$ ), 3.20 (q, $4 \mathrm{H}, \underline{\mathrm{CH}_{2}}-\mathrm{CH}_{3}$ ), 7.67 and 8.97 (dd, $2 \mathrm{H}$, pyrimidine ring; $\mathrm{J}_{6,7}=4.6 \mathrm{~Hz}$ ), 7.98 and 8.28 (dd, $4 \mathrm{H}, \mathrm{AB}-\mathrm{ArH} ; \mathrm{J}=8.4 \mathrm{~Hz}$ ), 8.72 (s, $1 \mathrm{H}, \mathrm{CH}$ Triazole); Anal. calcd. for $\mathrm{C}_{15} \mathrm{H}_{17} \mathrm{~N}_{5} \mathrm{O}_{2} \mathrm{~S}: \mathrm{C}, 54.36 ; \mathrm{H}, 5.17 ; \mathrm{N}$, 21.13. Found: C, 54.22; H, 5.04; N, 21.04.

General procedure for preparation of (13a,b).

A mixture of enaminone $2(0.01 \mathrm{~mol})$ and 5-amino-3-(methylthio)-1H-pyrazole-4-carbonitrile or 3-phenyl$1 \mathrm{H}$-pyrazol-5-amine $(0.01 \mathrm{~mol})$ in ethanol $(60 \mathrm{ml})$ was heated under reflux for $5 \mathrm{hr}$. During the reflux period, a crystalline solid was separated. The separated solid was filtered off, washed with ethanol and recrystallized from the appropriate solvents to give (13a,b).

4-(3-Cyano-2-(methylthio)pyrazolo[1,5-a]pyrimidin-7-yl)-N,N-diethylbenzenesulfonamide (13a).

Color: brownish yellow; Yield: 75\%; M.p.: $265-267^{\circ} \mathrm{C}$; FT-IR $\left(\mathrm{KBr}, v, \mathrm{~cm}^{-1}\right)$ : 2976 (CH-aliph.), 2220 (CN), 1352, $1154\left(\mathrm{SO}_{2}\right) ;{ }^{1} \mathrm{HNMR}\left(300 \mathrm{MHz}, \mathrm{DMSO}-d_{6}, \delta\right.$, ppm): 1.04 (t, $\left.6 \mathrm{H}, \mathrm{CH}_{3}-\mathrm{CH}_{2}\right), 2.68\left(\mathrm{~s}, 3 \mathrm{H}, \mathrm{SCH}_{3}\right), 3.21$ (q, $4 \mathrm{H}, \mathrm{CH}_{2}-\mathrm{CH}_{3}$ ), 7.54 and 8.82 (dd, $2 \mathrm{H}$, pyrimidine ring; $\mathrm{J}_{5,6}=4.6 \mathrm{~Hz}$ ), 7.98 and 8.28 (dd, $4 \mathrm{H}, \mathrm{AB}-\mathrm{ArH} ; \mathrm{J}=9.1$ $\mathrm{Hz}$ ); MS (EI, $\mathrm{m} / \mathrm{z}(\%)): 401\left(\mathrm{M}^{+}\right)(26.4), 265$ (100); Anal. calcd. for $\mathrm{C}_{18} \mathrm{H}_{19} \mathrm{~N}_{5} \mathrm{O}_{2} \mathrm{~S}_{2}$ : C, 53.85; H, 4.77; N, 17.44. Found: C, 53.71; H, 4.62; N, 17.31 .

4-(2-Phenylpyrazolo[1,5-a]pyrimidin-7-yl)-N,N-diethylbenzenesulfonamide (13b).

Color: yellow; Yield: 68\%; M.p.: $150^{\circ} \mathrm{C}-152^{\circ} \mathrm{C}$; FT-IR (KBr, v, $\left.\mathrm{cm}^{-1}\right): 2970$ (CH-aliph.), 1352, $1154\left(\mathrm{SO}_{2}\right)$; MS (EI, $m / z(\%)): 406\left(\mathrm{M}^{+}\right)(32.6), 270$ (100); Anal. calcd. for $\mathrm{C}_{22} \mathrm{H}_{22} \mathrm{~N}_{4} \mathrm{O}_{2} \mathrm{~S}$ : C, 65.00; H, 5.46; N, 13.78. Found: C, 64.85; H, 5.32; N, 13.64 .

4-(5-Hydroxybenzofuran-3-carbonyl)-N,N-diethyl-benzenesulfonamide (17).

To a stirred solution of enaminone (1; $0.01 \mathrm{~mol})$ in glacial acetic acid (30 ml), 1,4-benzoquionone ( $0.01 \mathrm{~mol})$ was added, stirring was continued for $7 \mathrm{hr}$. At room temperature, the reaction mixture was evaporated in vacuo and the solid product was isolated by filtration and recrystallized to give (17). Color: white; Yield: 78\%; M.p. $235^{\circ} \mathrm{C}-237^{\circ} \mathrm{C}$; FT-IR $\left(\mathrm{KBr}, v, \mathrm{~cm}^{-1}\right)$ : $3320(\mathrm{OH}), 1614(\mathrm{CO}), 1340,1156\left(\mathrm{SO}_{2}\right) ;{ }^{1} \mathrm{HNMR}(300 \mathrm{MHz}$, DMSO-d $\delta$, ppm): 1.03 (t, $6 \mathrm{H}, \mathrm{CH}_{3}-\mathrm{CH}_{2}$ ), 3.19 (q, $4 \mathrm{H}, \mathrm{CH}_{2}-\mathrm{CH}_{3}$ ), 6.84 and 7.52 (dd, $2 \mathrm{H}, \mathrm{H}-6,7$ benzofuran), 7.49 (s, $1 \mathrm{H}$, H-4 benzofuran), 7.93-8.02 (dd, 4H, AB-ArH; J = 7.65 Hz), 8.62 (s, 1H, H-2 benzofuran), 9.52 (s, 1H, OH exchangeable with $\mathrm{D}_{2} \mathrm{O}$ ); ${ }^{13} \mathrm{C}-\mathrm{NMR}\left(\mathrm{DMSO}_{6}\right) \delta: 14.7,40.3,107.0,112.6,115.2,125.8127 .6,130.0,142.3$, 143.3, 149.5, 155.4, 156.1, 191.4. Anal. Calcd. for $\mathrm{C}_{19} \mathrm{H}_{19} \mathrm{NO}_{5} \mathrm{~S}$ : C, 61.11; H, 5.13; N, 3.75. Found: C, 61.05; H, 5.09; N, 3.70 .

N-(6-(4-(N,N-diethylsulfamoyl)phenyl)-2-oxo-2H-pyran-3-yl)benzamide (19).

A mixture of enaminone $2(0.01 \mathrm{~mol})$ and benzoylglycine $(0.01 \mathrm{~mol})$ in acetic anhydride $(30 \mathrm{ml})$ was heated under reflux for $2 \mathrm{hr}$. The reaction mixture was concentrated in vacuo. The solid product which formed upon cooling was filtered off then washed with ethanol. Color: white; Yield:73\%; M.p.: $255^{\circ} \mathrm{C}-257^{\circ} \mathrm{C}$; FT-IR (KBr, $v, \mathrm{~cm}^{-1}$ ): 3336 (NH), 2972 (CH-aliph.), 1700 and 1660 (2CO), 1334, $1154\left(\mathrm{SO}_{2}\right) ;{ }^{1} \mathrm{HNMR}$ (300 MHz, DMSO-d $d_{6}$, $\delta$, ppm): 1.02 (t, $6 \mathrm{H}, \mathrm{CH}_{3}-\mathrm{CH}_{2}$ ), 3.15 (q, $4 \mathrm{H}, \mathrm{CH}_{2}-\mathrm{CH}_{3}$ ), 7.32 and 8.22 (dd, $2 \mathrm{H}$, pyranone; $\mathrm{J}=7.6 \mathrm{~Hz}$ ), 7.53 8.03 (m, 9H, ArH), 9.69 (s, 1H, NH); ${ }^{13} \mathrm{C}-\mathrm{NMR}$ (300 MHz, DMSO-d 6 , $\delta$, ppm): 14.6, 40.2, 91.1, 109.1, 126.1, 128.2, 129.1, 129.3, 135.2, 140.1, 158.2, 163.2, 163.6; Anal. calcd. for $\mathrm{C}_{22} \mathrm{H}_{22} \mathrm{~N}_{2} \mathrm{O}_{4} \mathrm{~S}$ : C, 64.37; H, 5.40; N, 6.82. Found: C, 64.24; H, 5.25; N, 6.68.

General Procedure for the Reaction of 2 with Active Methylene Compounds to Form ( 20a,b) and (21).

Sodium ethoxide solution ( $0.23 \mathrm{~g}$ sodium metal in $25 \mathrm{ml}$ absolute ethanol) was added with stirring to a mixture of $2(0.01 \mathrm{~mol})$ and cyanoacetamide, cyanothioacetamide and malononitrile dimer $(0.01 \mathrm{~mol})$ in absolute 
ethanol $(25 \mathrm{ml})$. The reaction mixture was refluxed for $3 \mathrm{~h}$, then poured into cooled water $(50 \mathrm{ml})$ and neutrallized with diluted hydrochloric acid. The precipitate that formed was filtered off, dried, and crystallized from the appropriate solvents to give:

4-(5-Cyano-6-oxo-1,6-dihydropyridin-2-yl)-N,N-diethylbenzenesulfonamide (20a).

Color: yellow; Yield: 77\%; M.p.: $220^{\circ} \mathrm{C}-222^{\circ} \mathrm{C}$; FT-IR (KBr, $\left.v, \mathrm{~cm}^{-1}\right)$ : 2926(CH-aliph.), 2226 (CN), 1648 (CO), 1332, $1156\left(\mathrm{SO}_{2}\right) ;{ }^{1} \mathrm{HNMR}$ (300 MHz, DMSO-d $d_{6}, \delta$, ppm): 1.02 (t, $6 \mathrm{H}, \mathrm{CH}_{3}-\mathrm{CH}_{2}$ ), 3.19 (q, $4 \mathrm{H}, \underline{\mathrm{CH}_{2}}-\mathrm{CH}_{3}$ ), 7.87 - $8.47(\mathrm{~m}, 7 \mathrm{H}, \mathrm{ArH}+\mathrm{NH})$; $\mathrm{MS}(\mathrm{EI}, \mathrm{m} / \mathrm{z}(\%))$ : $331\left(\mathrm{M}^{+}\right)(13.8)$, 64 (100); Anal. calcd. for $\mathrm{C}_{16} \mathrm{H}_{17} \mathrm{~N}_{3} \mathrm{O}_{3} \mathrm{~S}: \mathrm{C}$, 57.99; H, 5.17; N, 12.68. Found: C, 57.84; H, 5.03; N, 12.55.

4-(5-Cyano-6-mercaptopyridin-2-yl)-N,N-diethylbenzenesulfonamide (20b).

Color: yellowish white; Yield: 65\%; M.p.: $234^{\circ} \mathrm{C}-236^{\circ} \mathrm{C}$; FT-IR $\left(\mathrm{KBr}, v, \mathrm{~cm}^{-1}\right)$ : $3114(\mathrm{NH}), 2938(\mathrm{CH}-$ aliph.), 2224 (CN), 1334, $1154\left(\mathrm{SO}_{2}\right)$; MS (EI, m/z (\%)): $347\left(\mathrm{M}^{+}\right)(24.1), 84$ (100); Anal. calcd. for $\mathrm{C}_{16} \mathrm{H}_{17} \mathrm{~N}_{3} \mathrm{O}_{2} \mathrm{~S}_{2}$ : C, 55.31; H, 4.93; N, 12.09. Found: C, 55.17; H, 4.80; N, 11.95.

4-(5-Cyano-6-(dicyanomethylene)-1,6-dihydropyridin-2-yl)-N,N-diethylbenzenesulfonamide (21).

Color: yellow; Yield: 68\%; M.p.: $296^{\circ} \mathrm{C}-298^{\circ} \mathrm{C}$; FT-IR $\left(\mathrm{KBr}, v, \mathrm{~cm}^{-1}\right)$ : $3240(\mathrm{NH}), 2214(\mathrm{CN}), 1328,1156$ $\left(\mathrm{SO}_{2}\right)$; MS (EI, $\left.\mathrm{m} / \mathrm{z}(\%)\right): 379\left(\mathrm{M}^{+}\right)$(12.2), 55 (100); Anal. calcd. for $\mathrm{C}_{19} \mathrm{H}_{17} \mathrm{~N}_{5} \mathrm{O}_{2} \mathrm{~S}$ : C, 60.14; H, 4.52; N, 18.46. Found: C, 60.01; H, 4.37; N, 18.32 .

General procedure for preparation of (23a,b).

To a mixture of enaminone $2(0.01 \mathrm{~mol})$ and thiourea or guanidine hydrochloride $(0.01 \mathrm{~mol})$ in ethanol $(40 \mathrm{ml})$ was added a few drops of piperidine as catalyst. The reaction mixture was refluxed for $4 \mathrm{hr}$, then poured into cold water $(50 \mathrm{ml})$ and neutralized with diluted hydrochloric acid. The precipitate that formed was filtered off, dried, and crystallized from the appropriate solvents to give:

4-(2-Thioxo-1,2-dihydropyrimidin-4-yl)-N,N-diethyl-benzenesulfonamide (23a).

Color: faint brown; Yield: 82\%; M.p.: $190^{\circ} \mathrm{C}-192^{\circ} \mathrm{C}$; FT-IR $\left(\mathrm{KBr}, v, \mathrm{~cm}^{-1}\right)$ : 3126 (NH), 2976 (CH-aliph.), 1336, $1164\left(\mathrm{SO}_{2}\right)$; ${ }^{1} \mathrm{HNMR}$ (300 MHz, DMSO-d 6 , $\delta$, ppm): 1.05 (t, $\left.6 \mathrm{H}, \mathrm{CH}_{3}-\mathrm{CH}_{2}\right), 3.17$ (q, $\left.4 \mathrm{H}, \mathrm{CH}_{2}-\mathrm{CH}_{3}\right), 7.47$ and 8.16 (dd, 2H, pyrimidine ring; $\mathrm{J}=6.6 \mathrm{~Hz}$ ), 7.93 and 8.31 (dd, $4 \mathrm{H}, \mathrm{AB}-\mathrm{ArH} ; \mathrm{J}=8.4 \mathrm{~Hz}$ ), $13.8(\mathrm{~s}, 1 \mathrm{H}, \mathrm{NH})$; MS (EI, m/z (\%)):323 (M+)(25.5), 308 (78.4), 187 (100); Anal. calcd. for $\mathrm{C}_{15} \mathrm{H}_{17} \mathrm{~N}_{5} \mathrm{O}_{2} \mathrm{~S}$ : C, 54.36; H, 5.17; N, 21.13. Found: C, 54.22; H, 5.04; N, 21.02.

4-(2-Aminopyrimidin-4-yl)-N,N-diethylbenzenesulfonamide (23b).

Color: yellow; Yield: $75 \%$; M.p.: $175^{\circ} \mathrm{C}-177^{\circ} \mathrm{C}$; FT-IR $\left(\mathrm{KBr}, v, \mathrm{~cm}^{-1}\right)$ : 3478, $3300\left(\mathrm{NH}_{2}\right), 3162$ (CH-arom.), 2980 (CH-aliph.), 1332, 1152 ( $\mathrm{SO}_{2}$ ); MS (EI, $\mathrm{m} / \mathrm{z}(\%)$ ): 306 (M $\left.\mathrm{M}^{+}\right)(19.0)$ ), 291 (62.0), 170 (100); Anal. calcd. for $\mathrm{C}_{14} \mathrm{H}_{18} \mathrm{~N}_{4} \mathrm{O}_{2} \mathrm{~S}$ : C, 54.88; H, 5.92; N, 18.29. Found: C, 54.73; H, 5.80; N, 18.15 .

General procedure for preparation of (24a,b).

A mixture of enaminone $2(0.01 \mathrm{~mol})$ and $p$-toluidine or $p$-phenitidine $(0.01 \mathrm{~mol})$ in a mixture of ethanol/acetic acid (50 ml) (1:1) was heated under reflux for $3 \mathrm{hr}$. During the reflux period, a crystalline solid was separated. The separated solid was filtered off, washed with ethanol and recrystallized from the appropriate solvents to give:

4-(3-(p-Tolylamino)acryloyl)-N,N-diethylbenzenesulfonamide (24a).

Color: yellow; Yield: 88\%; M.p.: $265^{\circ} \mathrm{C}-267^{\circ} \mathrm{C}$; FT-IR (KBr, v, $\mathrm{cm}^{-1}$ ): 3176 (NH), 2982 (CH-aliph.), 1644 (CO), 1334, $1154\left(\mathrm{SO}_{2}\right) ;{ }^{1} \mathrm{HNMR}$ (300 MHz, DMSO-d $d_{6}, \delta$, ppm): 1.02 (t, $6 \mathrm{H}, \mathrm{CH}_{3}-\mathrm{CH}_{2}$ ), 2.25 (s, 3H, $\mathrm{CH}_{3}$ ), 3.16 (q, $4 \mathrm{H}, \underline{\mathrm{CH}_{2}}-\mathrm{CH}_{3}$ ), 6.09 (d, $1 \mathrm{H}, \mathrm{COCH}, \mathrm{J}=7.6 \mathrm{~Hz}$ ), 7.94 (m, 1H, CH-NH), 7.07-7.15 (dd, 4H, AB-ArH; J = 8.4 $\mathrm{Hz}$ ), 7.85 - 7.96 (dd, $4 \mathrm{H}, \mathrm{AB}-\mathrm{ArH}$; $\mathrm{J}=8.4 \mathrm{~Hz}$ ), 12.10 (d, $1 \mathrm{H}$, NH exchangeable with $\mathrm{D}_{2} \mathrm{O}$ ); Anal. calcd. for $\mathrm{C}_{20} \mathrm{H}_{24} \mathrm{~N}_{2} \mathrm{O}_{3} \mathrm{~S}$ : C, 64.49; $\mathrm{H}, 6.49$; N, 7.52. Found: C, 64.32; H, 6.35; N, 7.40.

4-(3-((4-Ethoxyphenyl)amino)acryloyl)-N,N-diethylbenzenesulfonamide (24b).

Color: reddish yellow; Yield: 85\%; M.p.: $280^{\circ} \mathrm{C}-282^{\circ} \mathrm{C}$; FT-IR (KBr, $\left.v, \mathrm{~cm}^{-1}\right)$ : 3170 (NH), 2980 (CH-aliph.), 1628 (CO), 1342, $1156\left(\mathrm{SO}_{2}\right)$; ${ }^{1} \mathrm{HNMR}$ (300 MHz, DMSO-d $d_{6}, \delta$, ppm): 1.01 (t, $6 \mathrm{H}, \mathrm{CH}_{3}-\mathrm{CH}_{2}$ ), 1.27 (t, 3H, $\mathrm{CH}_{3}-\mathrm{CH}_{2} \mathrm{O}$ ), 3.15 (q, 4H, $\mathrm{CH}_{2}-\mathrm{CH}_{3}$ ), 3.97 (q, $\left.2 \mathrm{H}, \mathrm{OCH}_{2}-\mathrm{CH}_{3}\right), 6.06$ (d, $\left.1 \mathrm{H}, \mathrm{COCH}, \mathrm{J}=7.8 \mathrm{~Hz}\right), 7.92(\mathrm{~m}, 1 \mathrm{H}$, CH-NH ), 6.89 - 7.26 (dd, 4H, AB-ArH; J = 8.4 Hz), 7.83 - 8.06 (dd, 4H, AB-ArH; J = 8.4 Hz), 12.17 (d, 1H, NH exchangeable with $\mathrm{D}_{2} \mathrm{O}$ ); Anal. calcd. for $\mathrm{C}_{21} \mathrm{H}_{26} \mathrm{~N}_{2} \mathrm{O}_{4} \mathrm{~S}$ : C, 62.66; H, 6.51; N, 6.96. Found: C, 62.51; H, 6.36; N, 6.82.

\section{4-(3-Benzoyl-1-phenyl-1H-pyrazole-4-carbonyl)- $\mathrm{N}, \mathrm{N}$-diethylbenzenesulfonamide (30).}

To a mixture of enaminone $2(0.01 \mathrm{~mol})$ and the hydrazonoyl bromide $(85 ; 0.01 \mathrm{~mol})$ in benzene $(40 \mathrm{ml})$ an equivalent amount of triethylamine was added. The reaction mixture was heated under reflux for $2 \mathrm{hr}$. the solvent was distilled at reduced pressure and the residual viscous liquid was taken in ethanol then the resulting solid was collected by filtration, washed thoroughly with ethanol, dried and finally recrystallized to give the compound 30 . 
Color: yellow; Yield: 81\%; M.p.: $224^{\circ} \mathrm{C}-226^{\circ} \mathrm{C}$; FT-IR (KBr, v, $\mathrm{cm}^{-1}$ ): 2976 (CH-aliph.), 1660 (CO), 1336, 1154 $\left(\mathrm{SO}_{2}\right) ;{ }^{1} \mathrm{HNMR}\left(300 \mathrm{MHz}, \mathrm{DMSO}-d_{6}, \delta\right.$, ppm): 1.03 (t, $\left.6 \mathrm{H}, \mathrm{CH}_{3}-\mathrm{CH}_{2}\right), 3.14\left(\mathrm{q}, 4 \mathrm{H}, \mathrm{CH}_{2}-\mathrm{CH}_{3}\right), 7.21-8.41$ (m, $15 \mathrm{H}, \mathrm{ArH}+\mathrm{CH}$ pyrazole); MS (EI, $\mathrm{m} / \mathrm{z}(\%)): 478\left(\mathrm{M}^{+}\right)(8.5)$, 351 (18.9.3), $76(100)$; Anal. calcd. for $\mathrm{C}_{27} \mathrm{H}_{25} \mathrm{~N}_{3} \mathrm{O}_{4} \mathrm{~S}$ : C, 66.51; H, 5.17; N, 8.62. Found: C, 66.37; H, 5.04; N, 8.48.

4-(2,7-Diphenyl-2H-pyrazolo[3,4-d]pyridazin-4-yl)-N,N-diethylbenzenesulfonamide (31).

A mixture of pyrazole derivative $30(0.01 \mathrm{~mol})$ and hydrazine hydrate $(0.012 \mathrm{~mol})$ in ethanol $(50 \mathrm{ml})$ was heated under reflux for $4 \mathrm{hr}$. The separated solid was filtered off, washed with ethanol and recrystallized to give 31. Color: brownish yellow; Yield: 65\%; M.p.: $292^{\circ} \mathrm{C}-294^{\circ} \mathrm{C}$; FT-IR $\left(\mathrm{KBr}, v, \mathrm{~cm}^{-1}\right)$ : 2974 (CH-aliph.), 1332, $1160\left(\mathrm{SO}_{2}\right)$; MS (EI, $\left.\mathrm{m} / \mathrm{z}(\%)\right): 483\left(\mathrm{M}^{+}\right)$(37.6), 347 (100); Anal. calcd. for $\mathrm{C}_{27} \mathrm{H}_{25} \mathrm{~N}_{5} \mathrm{O}_{2} \mathrm{~S}: \mathrm{C}, 67.06 ; \mathrm{H}, 5.21 ; \mathrm{N}$, 14.48. Found: C, 66.92; H, 5.08; N, 14.33 .

\subsection{Molecular Modeling Study}

\subsubsection{Generation of Ligand and Enzyme}

Structures. Selection of COX Structures.

Docking study was carried out for the target compounds into COX-1 (ID: 3N8Y) and COX-2 (ID: 1PXX) using MVD, 4.0 and MOE, 10. The crystal structure of the (COX) complexes with (1), which a selective inhibitor of COX-2 in co-crystallized form in the active site of the receptor. From X-ray crystal structure studies of the COX enzyme, the mouse enzyme is expected to be very similar to the human [28], and can be used as a model for human COX enzyme.

\subsubsection{Preparation of Small Molecule}

Molecular modeling of the target compounds were built using MOE, and minimized their energy with PM3 through MOPAC. Our compounds were introduced into the (COX) binding site accordance the published crystal structures of (1) bound to the kinase.

\subsubsection{Stepwise Docking Method \\ MOE Stepwise}

The crystal structure of the (COX) with a Diclofenac (1) as inhibitor molecule, was used in the receptor molecule, water and inhibitor molecules were removed, and hydrogen atoms were added. The parameters and charges were assigned to the MMFF94x force field. After alpha-site spheres were generated using the SITE FINDER module of MOE. The optimized 3D structures of molecules were subjected to generate different poses of ligands using triangular matcher placement method, which generating poses by aligning ligand triplets of atoms on triplets of alpha spheres representing in the receptor site points, a random triplet of alpha sphere centers is used to determine the pose during each iteration. The pose generated was rescored using London dG scoring function. The poses generated were refined with MMFF94x forcefield, also, the solvation effects were treated. The Born solvation model (GB/VI) was used to calculate the final energy, and the finally assigned poses were assigned a score based on the free energy in $\mathrm{kJ} / \mathrm{mol}$

\section{Results and Discussion.}

\subsection{Chemistry}

Treatment of 4-acetyl-N,N-diethylbenzenesulfonamide (1) with dimethylformamid-dimethylacetal (DMF-DMA) in dry dioxane afforded (E)-4-(3-(dimethylamino) acryloyl)-N,N-diethylbenzenesulfonamid (2) in high yield. (Scheme 1). The structure of the enaminone 2 was confirmed on the basis of elemental analysis and spectral data. Thus, the IR spectrum of compound 2 revealed absorption bands at $\left(\mathrm{v} \mathrm{cm}^{-1}\right)$ : $2910(\mathrm{CH}$-aliph.) and $1646(\mathrm{C}=$ O), while its ${ }^{1} \mathrm{H}$-NMR $(\delta \mathrm{ppm})$ spectrum (DMSO) indicated signals at: 2.90 and $3.13\left(2 \mathrm{~s}, 6 \mathrm{H}, \mathrm{N}\left(\mathrm{CH}_{3}\right)_{2}\right), 5.79$ and 7.72 (dd, $2 \mathrm{H}$, olefinic $\mathrm{CH}=\mathrm{CH} ; \mathrm{J}=12.25 \mathrm{~Hz}$ ), which support that the structure in (E-form), not (Z-form). The reactivity of compound 2 towards some nitrogen nucleophiles was investigated. Thus, enaminone 2 was treated with hydrazine hydrate in refluxing ethanol/acetic, to produce intermediates 3 followed by acetylation to give 4-(1-acetyl-1H-pyrazol-3-yl)-N,N-diethylbenzenesulfonamide (4). In the same manner, the enaminone 2 reacted with 2-cyanoacetic acid hydrazide under the same experimental reaction conditions to afford 4-(1-(2cyanoacetyl)-1H-pyrazol-3-yl)-N,N-diethylbenzenesulfonamide (5) (Scheme 1).

When compound 2 was allowed to react with active methylene reagent like: 2-cyanomethylbenzoimidazole in 


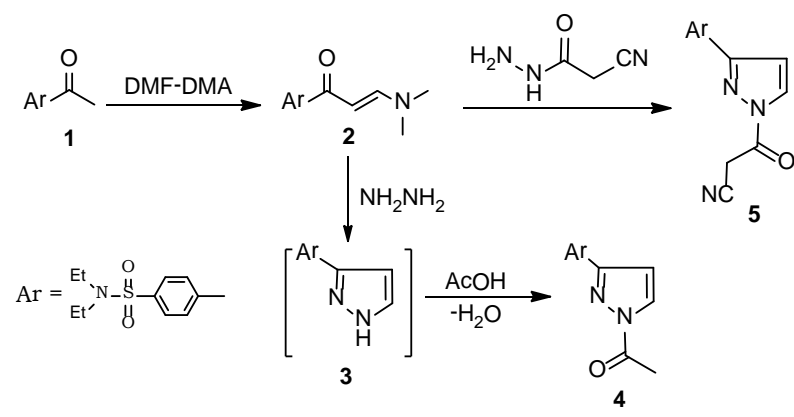

Scheme 1. Synthesis of pyrazole derivatives.

glacial acetic acid afforded 4-(4-cyanobenzo[4,5]imidazo [1,2-a] pyridin-1-yl)-N,N-diethylbenzenesulfonamide (7). Formation of 7 is assumed to proceed via the initial nucleophilic addition of the active methylene to enaminone double bond to afford the non-isolable intermediate 6 followed by elimination of water and dimethylamine (Scheme 2). On the other hand, the enaminone 2 condensed with 6-amino-2-thiouracil in glacial acetic acid at reflux temperature to afford N,N-diethyl-4-(8-oxo-6-thioxo-7,8-dihydro-6H-pyrimido[1,6-a] pyrimidin-4-yl) benzenesulfonamide (8), (Scheme 2). Enaminone 2 reacted with 3-amino-1H-1,2,4-triazole in acetic acid under reflux to afford $[1,2,4]$ triazolo[4,3-a]pyrimidine derivatives (10) via the addition of the exoamino group of aminotriazole to $\alpha, \beta$-unsaturated moiety in compound 2 followed by elimination of dimethylamine molecule to yield the corresponding acyclic non-isolable intermediate, which undergoes intramolecular cyclization by elimination of water molecule to afford the final product 10 not 9 (Scheme 2).

In the same manner, the enaminone 2 reacted with another heterocyclic amine like: 5-amino-3-methyl thiopyrazole-4-carbonitrile [29] [30] and 5-Phenyl-2H-pyrazol -3-yl amine under the same experimental reaction conditions to afford pyrazolo [1,5-a]pyrimidine derivatives $13 \mathrm{a}, \mathrm{b}$. The formation of $13 \mathrm{a}$,b was assumed to takes place via the addition of exoamino group of aminopyrazole to $\alpha, \beta$-unsaturated moiety of enaminone 2 to yield the corresponding acyclic non-isolable intermediate 12a,b which undergoes intramolecular cyclization by the elimination of the dimethylamine and water molecules to afford the final product 13a,b not 11a,b (Scheme 3).

Furthermore, Compound 2 reacted with 1,4-benzoquin-one in glacial acetic acid at room temperature to yield a product which formulated as N,N-diethyl-4-(5-hydroxy-benzofuran-3-carbonyl)benzenesulfonamide (17). Elucidation of structure 17 and refusing of structure 15 was based on ${ }^{1} \mathrm{H}-\mathrm{NMR}$ spectrum which indicates the disappearance of aldehydic signal and showed singlet signal at $9.52 \mathrm{ppm}$ for H-2 benzofuran moiety. It's believed that electron rich (C-2) in the enaminone 2 initially adds to the activated double bond in the quinone yielding acyclic intermediate 16 which then cyclizes into 17 via dimethylamine elimination, and not afforded 15 (Scheme 4).

Enaminone 2 reacted with hippuric acid in acetic anhydride to give a product that was identified as N-(6-(4(N,N-diethylsulfamoyl)phenyl)-2-oxo-2H-pyran-3-yl)benzamide (19), which confirmed on the basis of elemental analysis and spectral data, (Scheme 5). The formation of compound 19 was assumed to proceed via initial cyclization of hippuric acid into oxazolone derivative which then added to the activated double bond system of enaminone yielding 18 followed by intramolecular cyclization and rearrangement to give the final structure 19 (Scheme 5).

The reaction of 2 with some active nitriles such as cyanoacetamide, cyanothioacetamide and malononitrile dimer in sodium ethoxide was studied. Enaminones 2 were reacted with cyanoacetamide, cyanothioacetamide in refluxing ethanolic sodium ethoxide to give 4-(5-cyano-6-substituted pyridin-2-yl)-N,N-diethyl benzenesulfonamide 20a,b, (Scheme 6). Structures 20a,b were based on the correct elemental analyses and spectral data. Compound 2 was also reacting with malononitrile dimmer in refluxing ethanolic sodium ethoxide to give 4-(5-cyano-6-(dicyanomethylene)-1,6-dihydropyridin-2-yl)-N,N-diethylbenzenesulfonamide (21). All analyti$\mathrm{cal}$ and spectral data supported the suggested structure. The IR spectra showed an absorption band at 2214 (CN) $\mathrm{cm}^{-1}$.

Enaminone 2 reacted with guanidine hydrochloride and thiourea in refluxing ethanol in the presence of pipridine to give 23a,b. A plausible mechanism for the formation of compounds 23a,b is outlined in (Scheme 7). Which then undergo intramolecular cyclization and subsequent aromatization via the elimination of dimethylamine and water molecules under the reaction conditions to give 23a,b as depicted in (Scheme 7). On the other 


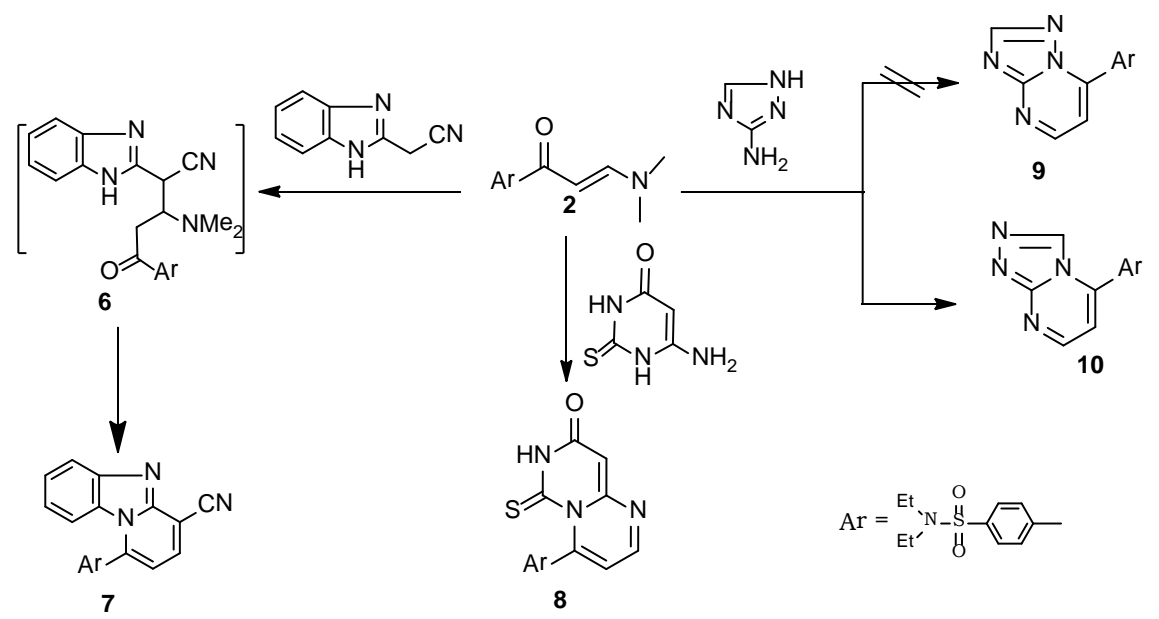

Scheme 2. Synthesis of benzoimidazo pyridine, pyrimido and triazolo pyrimidine derivatives.

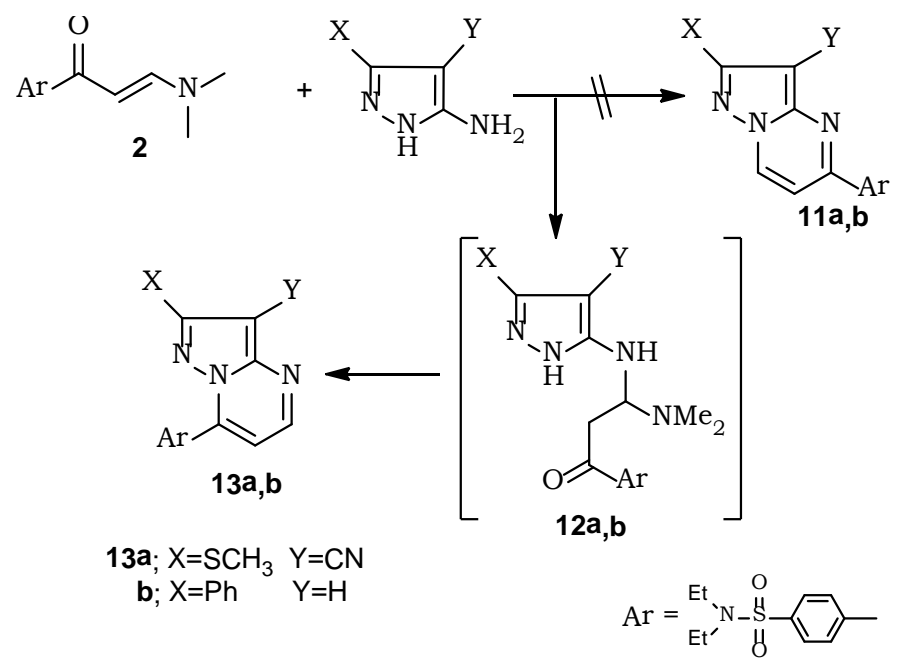

Scheme 3. Synthesis of pyrazolo pyrimidine derivatives.

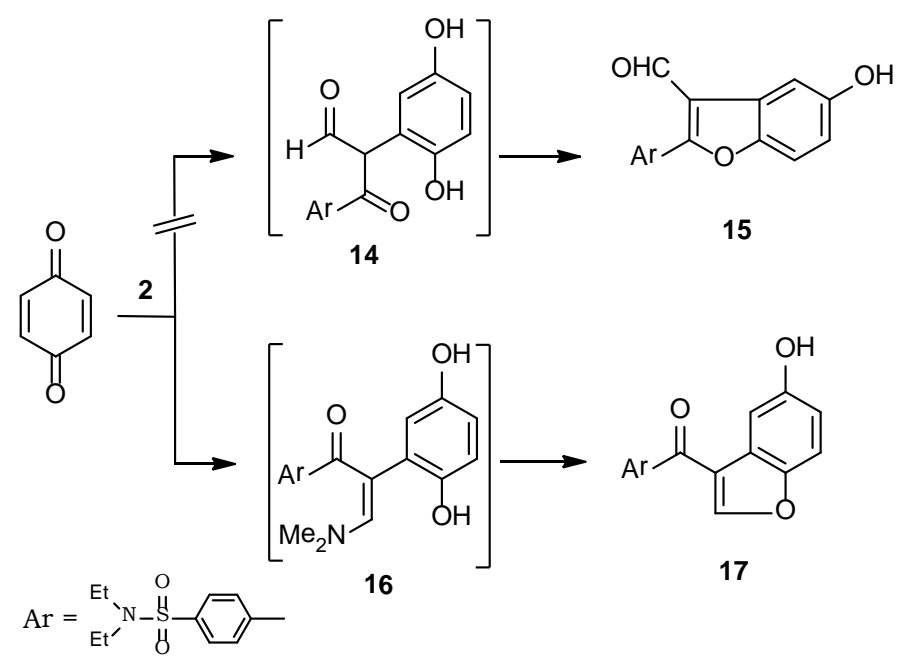

Scheme 4. Synthesis of benzofuran derivative. 
<smiles>O=C(O)CNC(=O)c1ccccc1</smiles>

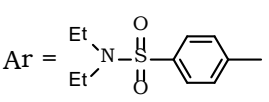<smiles>C[13CH2]c1ccc(NC(=O)c2ccccc2)c(=O)o1</smiles>

19

Scheme 5. Synthesis of pyranone derivative.

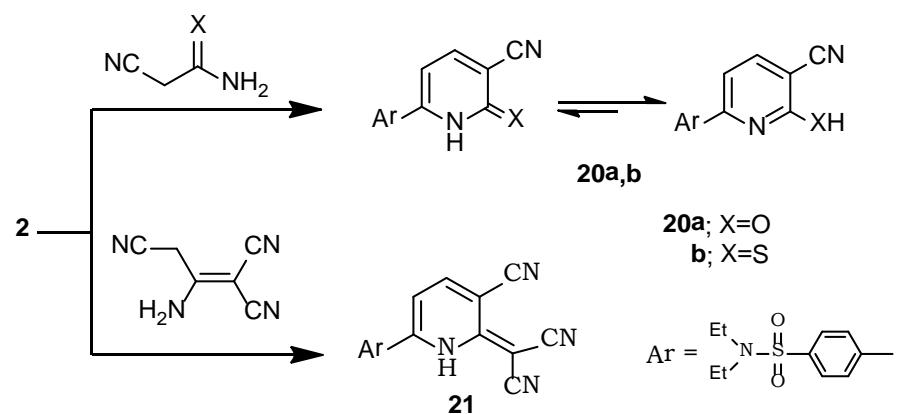

Scheme 6. Synthesis of pyridine derivative.

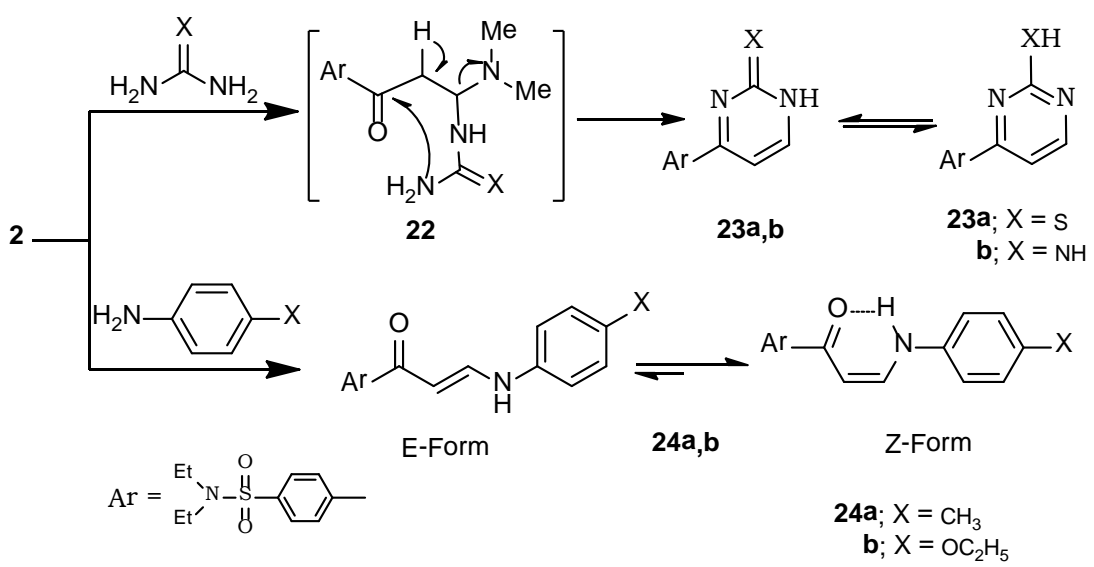

Scheme 7. Synthesis of pyrimidine derivatives.

hand, when enaminone (2) was treated with primary aromatic amines namely ( $p$-toluidine and $p$-phenitidine) in a mixture of ethanol/acetic acid at reflux temperature afforded 4-(3-((p-substituted amino)acryloyl)-N,N-diethylbenzene sulfonamides (24a,b) (Scheme 7). The ${ }^{1} \mathrm{H}-\mathrm{NMR}$ spectrum of compounds 24a,b support this structures is (Z-form) not (E-form), where the coupling constant of the doublet signals for olefinic protons equal to 7.6, 7.8 Hz, respectively. Stabilization of (Z-form) is achieved by intramolecular hydrogen bonding (Scheme 7).

Hydrazonyl halides [31]-[33] has been reported to add to $\alpha, \beta$-unsaturated carbonyl compounds to yield a mixture of isomeric pyrazolines [34] [35]. In the present work the reaction of enaminone 2 with nitrileimine 26 (gen- erated in situ from the treatment of the hydrazonoyl bromide 25 with triethylamine in refluxing $m$-xylene) gave only one isolable product (TLC). From which two proposed structures 28 or 30 seemed possible (Scheme 8). The other possible regioisomer 28 was excluded on the basis of the spectral data of the isolated products. For example, in the pyrazole ring system, $\mathrm{C}-4$ is the most electron-rich carbon, thus $\mathrm{H}-4$ is expected to appear in the ${ }^{1} \mathrm{H}-\mathrm{NMR}$ spectra at higher field, typically near $6.0 \mathrm{ppm}$. On the other hand, H-5 is linked to the carbon attached 


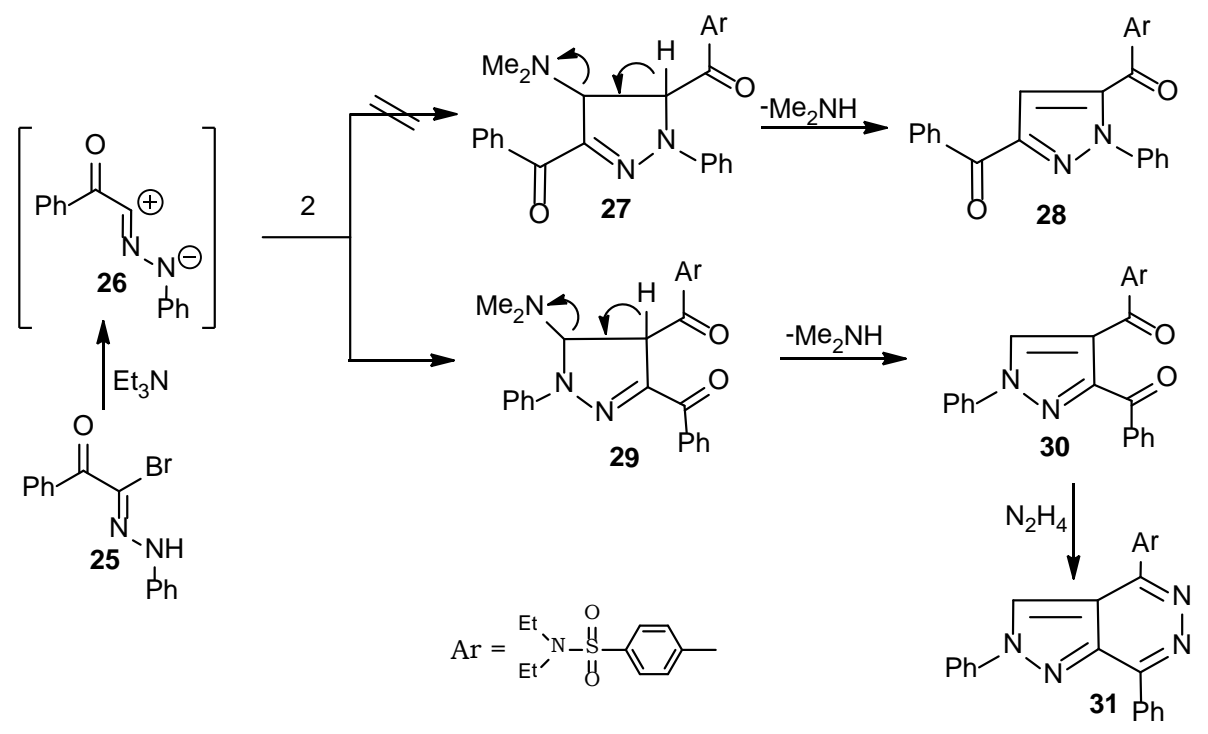

Scheme 8. Synthesis of pyrazolo pyridazine derivative.

to a nitrogen atom and thus it is deshielded to appear near $8.0 \mathrm{ppm} .{ }^{1} \mathrm{H}-\mathrm{NMR}$ spectrum of 30 exhibits a singlet at $8.41 \mathrm{ppm}$, which indicates the presence of the pyrazole H-5 rather than H-4 [36]. Pyrazole derivative 30 was assumed to be formed via initial 1, 3-dipolar cycloaddition of nitrileimine 26 to the activated double bond in compound 2 forming non isolable intermediate 29 followed by the loss of dimethylamine (Scheme 8). Interaction of pyrazole derivative 30 with hydrazine hydrate in refluxing ethanol absolute afforded pyrazolo[3,4-d] pyridazine derivative (31), which confirmed by elemental analysis and spectral data (Scheme 8).

\subsection{Docking Studies}

In brief, two isoforms of COX protein are known: COX-1 is responsible for the physiological production of prostaglandins, which is expressed in most tissues; and COX-2, is responsible for the increasing production of prostaglandins during process of inflammation, which is induced by endotoxins, cytokines and mitogens in inflammatory cells [37]. Recently, from analysis of X-ray cocrystal of arachidonic acid with COX-2 showed that, carboxylate coordinated with Tyr-385 and Ser-530 [38], as well as the action of NSAIDs, through the interaction carboxylate group with Tyr-385 and Ser-530, which stabilize the negative charge of the tetrahedral intermediate [39], and demonstrated that, Tyr-385 and Ser-530 have a structural and functional evidence for the importance of them in the chelating of the ligands [40]. Molecular docking of the synthesized compounds into the active site of COX was performed, in order to obtain biological data on a structural basis, through rationalized ligand-protein interaction behavior. All calculations for docking experiment were performed with MOE 2008.10 [41]. The tested compounds were evaluated in silico (docking), using X-ray crystal structures of COX-2 (ID: 4COX). The tested compounds were docked into active sites of both enzymes COX-2. The active site of the enzyme was defined to include residues within a $10.0 \AA$ radius to any of the inhibitor atoms. The scoring function of the most stable docking model for testing compounds was applied to evaluate the binding affinities of the inhibitors complexes with (COX) active site (Table 1). The complexes were energy-minimized with an MMFF94 force field [42] till the gradient convergence $0.05 \mathrm{kcal} / \mathrm{mol}$ was reached. The active compounds docked successfully into the COX-2 active site. The compounds 2.10 and 17 in COX-2 active site exhibited, binding scores (-98.09, -118.71 and -125.06$) \mathrm{Kcal} / \mathrm{mol}$, respectively.

Structure activity relationships:

In order to get a deeper insight into the nature and type of interactions of docked compounds, the complexes between each compound and COX-2 receptor were visualized, and depicted in (Figures 1-3). Since, the H bonds play an important role in the structure and function of biological molecules, the current ligand-receptor interactions were analyzed on the basis of $\mathrm{H}$ bonding. In order to reduce the complexity, hydrophobic and $\pi$-cation interactions ( $>6 \AA$ ) are not shown in the Figures 1-3.

On COX-2 binding site (Figure 3); i-Compound 2 arranged in the binding pocket by adjusting phenyl ring 
Table 1. Pharmacokinetic parameters important for good oral bioavailability of most active compounds.

\begin{tabular}{|c|c|c|c|c|c|c|}
\hline CPD & 2 & 4 & 7 & 8 & 10 & 17 \\
\hline HBD & 0 & 0 & 1 & 0 & 0 & 0 \\
\hline HBA & 7 & 5 & 6 & 7 & 6 & 6 \\
\hline CLogP & 1.803 & 1.162 & 2.933 & 0.964 & 1.514 & 3.559 \\
\hline $\mathbf{V}$ & 0 & 0 & 0 & 0 & 0 & 0 \\
\hline Vol. & 185 & 176.25 & 181.875 & 201 & 195.875 & 196.25 \\
\hline TPSA & 52.82 & 106.53 & 57.53 & 124.35 & 95.53 & 72.55 \\
\hline$\%$ ABS & 90.7771 & 72.24715 & 89.15215 & 66.09925 & 76.04215 & 83.97025 \\
\hline $\log S$ & -3.69206 & -2.42823 & -5.17052 & -3.32469 & -3.07276 & -5.45284 \\
\hline HОМо & -9.46936 & -8.95061 & -9.14457 & -9.95624 & -9.57443 & -8.68336 \\
\hline LUMO & -1.61311 & -0.77546 & -0.77307 & -1.1573 & -0.92765 & -1.25907 \\
\hline $\mathbf{m r}$ & 7.856251 & 8.17515 & 8.3715 & 8.79894 & 8.646781 & 7.42429 \\
\hline$\Delta \mathbf{E}$ & 3.928125 & 4.087575 & 4.18575 & 4.39947 & 4.32339 & 3.712145 \\
\hline$\eta$ & 0.254574 & 0.244644 & 0.238906 & 0.2273 & 0.2313 & 0.269386 \\
\hline S & -5.54124 & -4.86304 & -4.95882 & -5.55677 & -5.25104 & -4.97122 \\
\hline$\chi$ & 5.541235 & 4.863035 & 4.95882 & 5.55677 & 5.25104 & 4.971215 \\
\hline$\sigma$ & 3.90839 & 2.892804 & 2.937335 & 3.509251 & 3.188866 & 3.328666 \\
\hline$\omega$ & -9.46936 & -8.95061 & -9.14457 & -9.95624 & -9.57443 & -8.68336 \\
\hline
\end{tabular}

TPSA: Polar surface area $\left(\mathrm{A}^{2}\right)$; \%ABS: Absorption percentage; Vol: Volume $\left(\mathrm{A}^{3}\right)$; HBA: Number of hydrogen bond acceptor; HBD: Number of hydrogen bond donor; V: Number of violation from Lipinski’s rule of five; Log P: Calculated lipophilicity; Log S: Solubility parameter; mr: Molar Refractivity; $\Delta \mathrm{E}$ : Energy Gaps (ev); $\eta$ : Hardness (ev); S: Softness (ev); $\chi$ : Electronegativity (ev); $\sigma$ : chemical potential (ev); $\omega$ : Electrophilicity (ev).

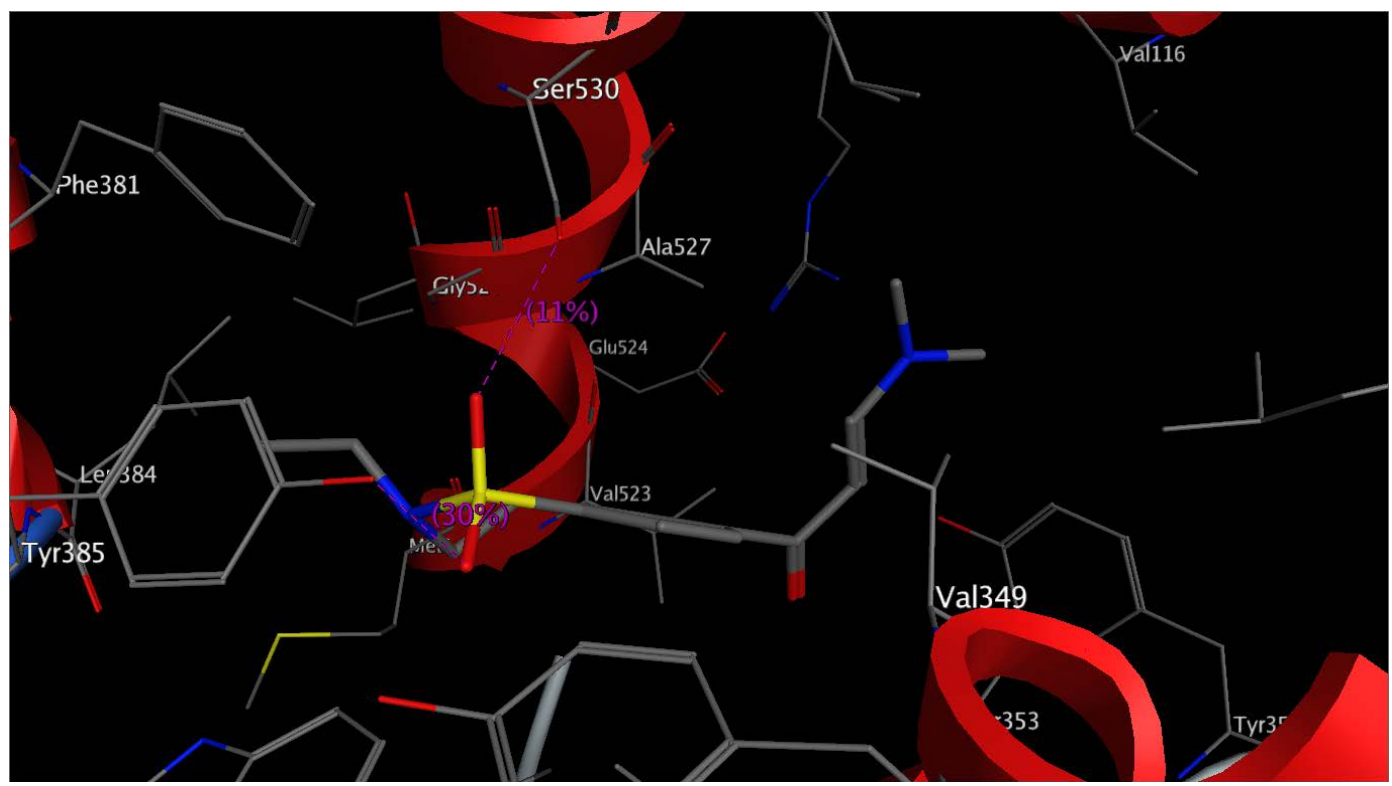

Figure 1. Docking compound 2 into the active site COX-2 with highest docking score H-bonds are in pink.

perpendicular with N-ethyl and formed an electrostatic bond with Ser-530 and Tyr-385; ii-Compound 10 and 17, were interacted with different modes with binding pocket, by forming two strong hydrogen bond interaction with important residue Arg-120, which explain increasing of the binding energy of its compounds. The results obtained clearly reveals that, the amino acid residues close to the reference molecules are mostly the same as those observed in the most active compounds complexes with protein (Figures 2 and 3). These results indicate that, the compounds 2, 10 and 17 act as selective inhibitors against COX-2.

ADMET factors profiling:

Oral bioavailability was considered to play an important role in the development of bioactive molecules as 


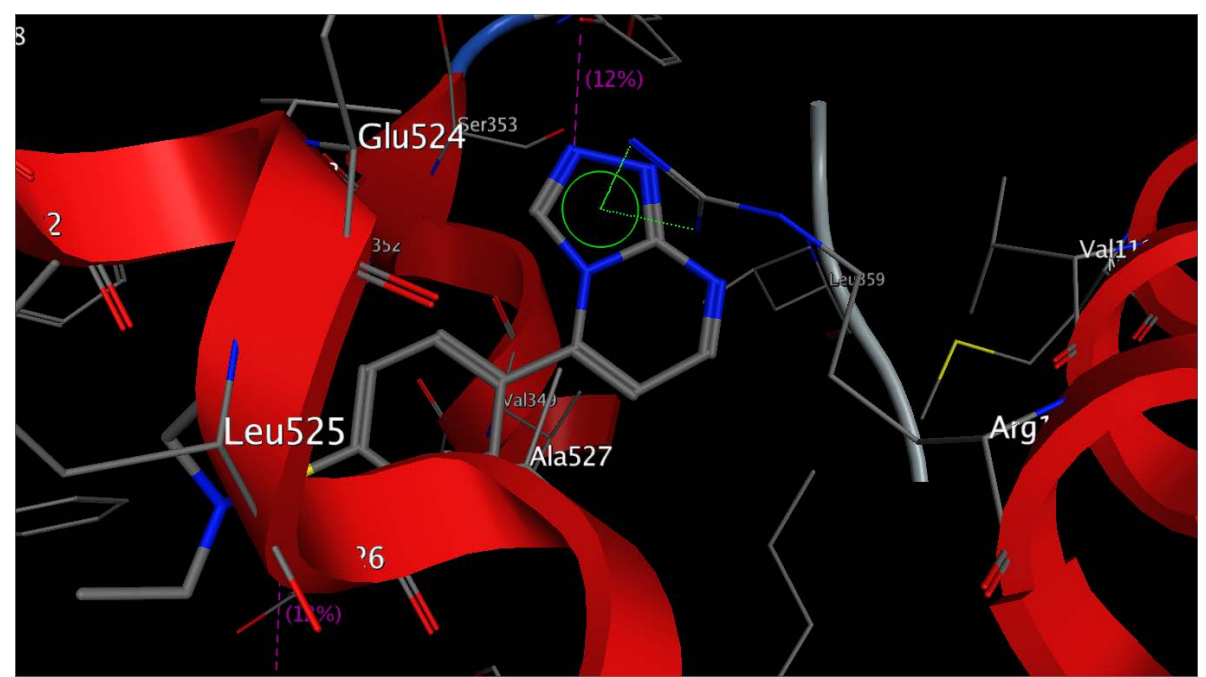

Figure 2. Docking compound 10 with a highest docking score into the active site COX-2.

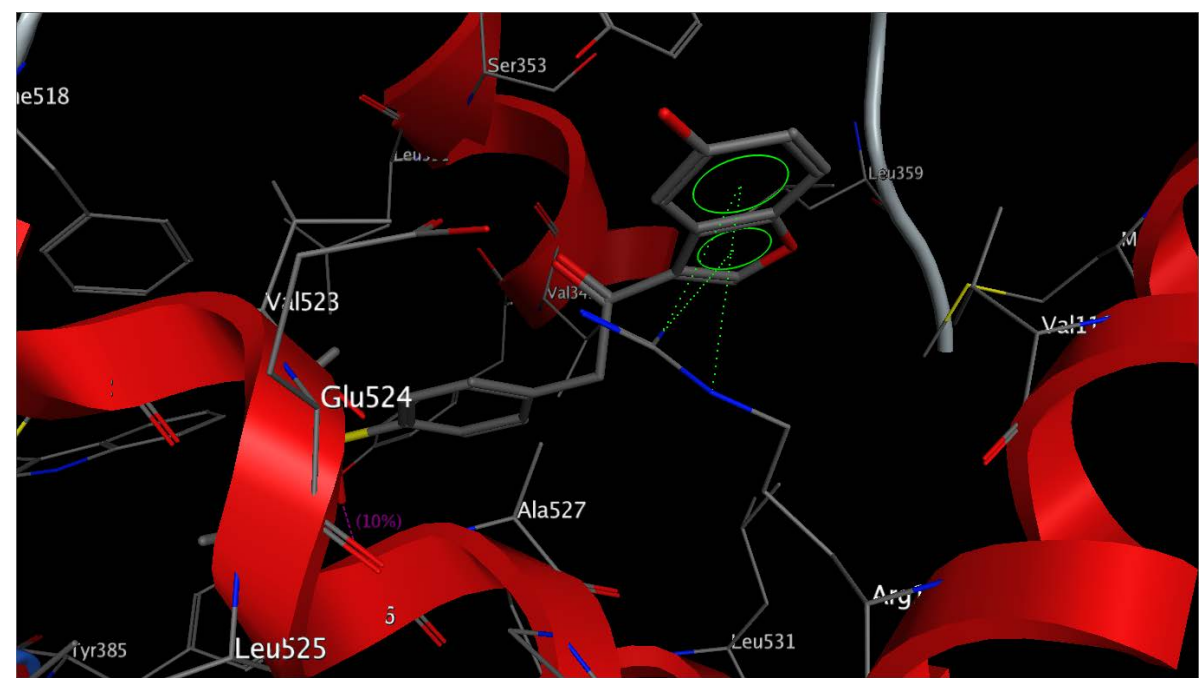

Figure 3. Docking compound 17 with a highest docking score into the active site COX-2.

therapeutic agents. Many potential therapeutic agents fail to reach the clinic, because of their ADMET (absorption, distribution, metabolism, elimination and toxic) Factors. Therefore, a computational study for prediction of ADMET properties of the molecules was performed for most active compounds, by the determination of topological polar surface area (TPSA), a calculated percent absorption (\%ABS) which was estimated by Zhao et al. equation [29], and "rule of five” formulated by Lipinski [30], which established that, chemical compound could be an orally active drug in humans, if no more than one violation of the following rule:

1) ClogP (partition coefficient between water and octanol) $<5$.

2) Number of hydrogen bond donor sites $\leq 5$.

3) Number of hydrogen bond acceptor sites $\leq 10$, iv), molecular weight $<500$.

In addition, the total polar surface area (TPSA) is another key property linked to drug bioavailability, the passively absorbed molecules with (TPSA > 140) have low oral bioavailability [43]. All calculated descriptors were performed using MOE Package, and their results were disclosed in Table 1. Our results revealed that, the CLogP (factor of the lipophilicity) [44] was less than 5.0, hydrogen bond acceptors between (5 and 7), hydrogen bond donors (1), this data show these compounds fulfill Lipinski's rule. Also, the absorption percent is ranged between ( 66\% - 90\%).

The HOMO and LUMO of a molecule play important roles in intermolecular interactions [33], through the 
interaction between the HOMO of the drug with the LUMO of the receptor and vice versa. The interactions were stabilized inversely with energy gap between the interacting orbitals. Increasing HOMO energy and decreasing LUMO energy in the drug molecule lead to enhancement stabilizing interactions, and hence, binding to the receptor. Furthermore, the global and local chemical reactivity descriptors for molecules have been defined (Table 1), like softness (measures stability of molecules and chemical reactivity), hardness (reciprocal of softness), chemical potential, electronegativity (strength atom for attracting electrons to itself), electrophilicity index (measuring lowering energy due to maximal flowing electron between donor and acceptor) [45]-[51]. The results were shown in Table 1 and may explain the less toxicity and high affinity of its compounds against COX.

\section{Acknowledgements}

This study was supported by the Chemistry Department, Faculty of Science, Al-Azhar University. We are deeply thankful to Micro Analytical Center for making the IR, ${ }^{1} \mathrm{H}$ NMR, ${ }^{13} \mathrm{C}$ NMR and MS samples.

\section{References}

[1] Ferraz, H.M.C. and Goncalo, E.R.S. (2007) Recent Preparations and Synthetic Applications of Enaminones. Química Nova, 30, 957-964. http://dx.doi.org/10.1590/S0100-40422007000400035

[2] Riyadh, S.M., Abdelhamid, I.A., Al-Matar, H.M., Hilmy, N.M. and Elnagdi, M.H. (2008) Enamines as Precursors to Polyfunctional Heteroaromatic Compounds; a Decade of Development. Heterocycles, 75, 1849-1905. http://dx.doi.org/10.3987/REV-07-625

[3] Elassar, A.Z.A. and El-Khair, A.A. (2003) Recent Developments in the Chemistry of Enaminones. Tetrahedron, 59, 8463-8480. http://dx.doi.org/10.1016/S0040-4020(03)01201-8

[4] Stanovnik, B. and Svete, J. (2004) Synthesis of Heterocycles from Alkyl 3-(Dimethylamino)Propenoates and Related Enaminones. Chemical Reviews, 104, 2433-2480. http://dx.doi.org/10.1021/cr020093y

[5] Yermolayev, S.A., Gorobets, N.Y., Lukinova, E.V., Shishkin, O.V., Shishkina, S.V. and Desenko, S.M. (2008) An Efficient Synthesis of N1-Substituted 2,5-Dioxo-1,2,5,6,7,8-Hexahydro-3-Quinolinecarboxamide via Enolate Salts. Tetrahedron, 64, 4649-4655. http://dx.doi.org/10.1016/j.tet.2008.02.095

[6] Gorobets, N.Y., Yousefi, B.H., Belaj, F. and Kappe, C.O. (2004) Rapid Microwave-Assisted Solution Phase Synthesis of Substituted 2-Pyridone Libraries. Tetrahedron, 60, 8633-8644. http://dx.doi.org/10.1016/j.tet.2004.05.100

[7] Drews, J. (2000) Drug Discovery: A Historical Perspective. Science, 287, 1960-1964. http://dx.doi.org/10.1126/science.287.5460.1960

[8] Supuran, C.T., Casini, A. and Scozzafava, A. (2003) Protease Inhibitors of the Sulfonamide Type: Anticancer, Antiinflammatory, and Antiviral Agents. Medicinal Research Reviews, 23, 535. http://dx.doi.org/10.1002/med.10047

[9] Supuran, C.T. and Scozzafava, A. (2000) Carbonic Anhydrase Inhibitors and Their Therapeutic Potential. Expert Opinion on Therapeutic Patents, 10, 575-600.

[10] Ghorab, M.M., Ragab, F.A., Heiba, H.I., Arafa, R.K. and El-Hossary, E.M. (2011) Docking Study, in Vitro Anticancer Screening and Radiosensitizing Evaluation of Some New Fluorine-Containing Quinoline and Pyrimidoquinoline Derivatives Bearing a Sulfonamide Moiety. Medicinal Chemistry Research, 20, 388-400. http://dx.doi.org/10.1007/s00044-010-9332-3

[11] Boyd 3rd, A.E. (1988) Sulfonylurea Receptors, Ion Channels, and Fruit Flies. Diabetes, 37, 847-850. http://dx.doi.org/10.2337/diab.37.7.847

[12] Kamel, M.M., Ali, H.I., Anwar, M.M., Mohamed, N.A. and Soliman, A.M. (2010) Synthesis, Antitumor Activity and Molecular Docking Study of Novel Sulfonamide-Schiff's Bases, Thiazolidinones, Benzothiazinones and Their CNucleoside Derivatives. European Journal of Medicinal Chemistry, 45, 572-580. http://dx.doi.org/10.1016/j.ejmech.2009.10.044

[13] Nair, B. and Taylor-Gjevre, R. (2010) A Review of Topical Diclofenac Use in Musculoskeletal Disease. Pharmaceuticals, 3, 1892-1908. http://dx.doi.org/10.3390/ph3061892

[14] Gabriel, S.E. and Matteson, E.L. (1995) Economic and Quality-of-Life Impact of NSAIDs in Rheumatoid Arthritis: A Conceptual Framework and Selected Literature Review. Pharmacoeconomics, 8, 479-490. http://dx.doi.org/10.2165/00019053-199508060-00004

[15] Zochling, J., Bohl-Bühler, M.H.J., Baraliakos, X., Feldtkeller, E. and Braun, J. (2006) Nonsteroidal Anti-Inflammatory Drug Use in Ankylosing Spondylitis-A Population-Based Survey. Clinical Rheumatology, 25, 794-800. http://dx.doi.org/10.1007/s10067-005-0132-y

[16] Hochberg, M.C. (2005) COX-2 Selective Inhibitors in the Treatment of Arthritis: A Rheumatologist Perspective. Cur- 
rent Topics in Medicinal Chemistry, 5, 443-448. http://dx.doi.org/10.2174/1568026054201695

[17] Warden, J.S. (2010) Prophylactic Use of NSAIDs by Athletes: A Risk/Benefit Assessment. The Physician and Sports Medicine, 38, 132-138. http://dx.doi.org/10.3810/psm.2010.04.1770

[18] Guyton, C.A. and Hall, J.E. (1998) Textbook of Medical Physiology. 9th Edition, Harcourt Asia Pte. Ltd.

[19] Vane, J.R., Bakhle, Y.S. and Bolting, R.M. (1998) Cyclooxygenases 1 and 2. Annual Review of Pharmacology and Toxicology, 38, 97-120. http://dx.doi.org/10.1146/annurev.pharmtox.38.1.97

[20] Guslandi, M. (1997) Gastric Toxicity of Antiplatelet Therapy with Low-Dose Aspirin. Drugs, 53, 1-5. http://dx.doi.org/10.2165/00003495-199753010-00001

[21] Mazumdar, K., Dutta, N., Dastidar, S., Motohashi, N. and Shirataki, Y. (2006) Diclofenac in the Management of E. coli Urinary Tract Infections. In Vivo, 20, 613-619.

[22] Dutta, N., Annadurai, S., Mazumdar, K., Dastidar, S.G., Kristiansen, J., Molnar, J., Martins, M. and Amaral, L. (2000) The Antibacterial Action of Diclofenac Shown by Inhibition of DNA Synthesis. International Journal of Antimicrobial Agents, 14, 249-251. http://dx.doi.org/10.1016/S0924-8579(99)00159-4

[23] Sriram, D., Yogeeswari, P. and Devakaram, R. (2006) Synthesis, in Vitro and in Vivo Antimycobacterial Activities of Diclofenac Acid Hydrazones and Amides. Bioorganic \& Medicinal Chemistry, 14, 3113-3118. http://dx.doi.org/10.1016/j.bmc.2005.12.042

[24] Bhandari, S., Bothara, K., Raut, M., Patil, A., Sarkate, A. and Mokale, J. (2008) Design, Synthesis and Evaluation of Anti-Inflammatory, Analgesic and Ulcerogenicity Studies of Novel S-Substituted Phenacyl-1,3,4-Oxadiazole-2-Thiol and Schiff Bases of Diclofenac Acid as Nonulcerogenic Derivatives. Bioorganic \& Medicinal Chemistry, 16, 1822 1831. http://dx.doi.org/10.1016/j.bmc.2007.11.014

[25] Amir, M. and Shikha, K. (2004) Synthesis and Anti-Inflammatory, Analgesic, Ulcerogenic and Lipid Peroxidation Activities of Some New 2-[(2, 6-Dichloroanilino) Phenyl]Acetic Acid Derivatives. European Journal of Medicinal Chemistry, 39, 535-545. http://dx.doi.org/10.1016/j.ejmech.2004.02.008

[26] Barbaric, M., Kralj, M., Marjanovic, M., Husnjak, I., Pavelic, K., Filipovic Grcic, J., Zorc, D. and Zorc, B. (2007) Synthesis and in Vitro Antitumor Effect of Diclofenac and Fenoprofen Thiolated and Nonthiolated PolyaspartamideDrug Conjugates. European Journal of Medicinal Chemistry, 42, 20-29. http://dx.doi.org/10.1016/j.ejmech.2006.08.009

[27] Oza, V., Smith, C., Raman, P., Koepf, E., Lashuel, H., Petrassi, H., Chiang, K., Powers, P., Sachettinni, J. and Kelly, J. (2002) Synthesis, Structure, and Activity of Diclofenac Analogues as Transthyretin Amyloid fibril Formation Inhibitors. Journal of Medicinal Chemistry, 45, 321-332. http://dx.doi.org/10.1021/jm010257n

[28] Ramesh, K., Narayana Murthy, S., Karnakar, K. and Nageswar, Y.V.D. (2011) DABCO-Promoted Three-Component Reaction between Amines, Dialkyl Acetylenedicarboxylates, and Glyoxal. Tetrahedron Letters, 52, 3937-3941. http://dx.doi.org/10.1016/j.tetlet.2011.05.100

[29] Hafiz, I.S. (2000) Enaminonitriles in Heterocyclic Synthesis: Synthesis of New 1, Dihydropyridine Pyrazolo [1, 5-a] Pyrimidine, Aminothiophene and Pyridine Derivatives. Zeitschrift fur Naturforschung, 55, 321.

[30] Kiefer, J.R., Pawlitz, J.L., Moreland, K.T., Stegeman, R.A., Hood, W.F., Gierse, J.K., Steven, A.M., Goodwin, D.C., Rowlinson, S.W., Marnett, L.J., Stallings, W.C. and Kurumbail, R.G. (2000) Structural Insights into the Stereochemistry of the Cyclooxygenase Reaction. Nature, 405, 97-101.

[31] Eweiss, N.F. and Osman, A. (1980) Synthesis of Heterocycles. Part II. New Routes to Acetylthiadiazolines and Alkylazothiazoles. Journal of Heterocyclic Chemistry, 17, 1713-1718. http://dx.doi.org/10.1002/jhet.5570170814

[32] Nagakura, M., Ota, T., Shimadzu, N., Kawamura, K., Eto, Y. and Wada, Y. (1979) Syntheses and Antiinflammatory Actions of 4,5,6,7-Tetrahydroindazole-5-Carboxylic Acids. Journal of Medical Chemistry, 22, 48-52. http://dx.doi.org/10.1021/jm00187a012

[33] Shawali, A.S. and Abdelhamide, A.O. (1976) Reaction of Dimethylphenacylsulfonium Bromide with $N$-Nitrosoacetarylamides and Reactions of the Products with Nucleophiles. Bulletin of the Chemical Society of Japan, 49, 321-324. http://dx.doi.org/10.1246/bcsj.49.321

[34] Al-Zaydi, K.M. (2003) Microwave Assisted Synthesis, Part 1: Rapid Solventless Synthesis of 3-Substituted Coumarins and Benzocoumarins by Microwave Irradiation of the Corresponding Enaminones. Molecules, 8, 541-555. http://dx.doi.org/10.3390/80700541

[35] Biere, H., Böttcher, I. and Kapp, J. (1983) Nonsteroidal Anti-Inflammatory Agents. 11. Antiphlogistic Pyrazole Derivatives, III. Archiv der Pharmazie (Weinheim), 316, 608-616.

[36] El-Taweel, F.M. and Elnagdi, M.H. (2001) Studies with Enaminones: Synthesis of New Coumarin-3-yl Azoles, Coumarin-3-yl Azines, Coumarin-3-yl Azoloazines, Coumarin-3-yl Pyrone and Coumarin-2-yl Benzo[b]Furans. Journal of Heterocyclic Chemistry, 38, 981-984. http://dx.doi.org/10.1002/jhet.5570380428 
[37] Hochgesang, G.P. and Marnett, L.J. (2000) Tyrosine-385 Is Critical for Acetylation of Cyclooxygenase-2 by Aspirin. Journal of the American Chemical Society, 122, 6514-6515. http://dx.doi.org/10.1021/ja0003932

[38] Rowlinson, S.W., Kiefer, J.R., Prusakiewcz, J.J., Pawlitz, J.L., Kozak, K.R., Kalgutkar, A.S., Stallings, W.C., Kurumbail, R.G. and Marnett, L. (2003) A Novel Mechanism of Cyclooxygenase-2 Inhibition Involving Interactions with Ser-530 and Tyr-385. Journal of Biological Chemistry, 278, 45763-45769. http://dx.doi.org/10.1074/jbc.M305481200

[39] Kurumbail, R.G., Stevens, A.M., Gierse, J.K., McDonald, J.J., Stegeman, R.A., Pak, J.Y., Gildehaus, D., Miyashiro, J.M., Penning, T.D., Seibert, K., Isakson, P.C. and Stallings, W.C. (1996) Structural Basis for Selective Inhibition of Cyclooxygenase-2 by Anti-Inflammatory Agents. Nature, 384, 644-648. http://dx.doi.org/10.1038/384644a0

[40] Sidhu, R.S., Lee, J.Y., Yuan, C. and Smith, W.L. (2010) Comparison of Cyclooxygenase-1 Crystal Structures: Cross-Talk between Monomers Comprising Cyclooxygenase-1 Homodimers. Biochemistry, 49, 7069-7079. http://dx.doi.org/10.1021/bi1003298

[41] Chemical Computing Group. Inc., MOE, 2009, 10.

[42] Halgren, T.A. (1996) Merck Molecular Force Field I. Basis, Form, Scope, Parameterization, and Performance of MMFF94. Journal of Computational Chemistry, 17, 490-519. http://dx.doi.org/10.1002/(SICI)1096-987X(199604)17:5/6<490::AID-JCC1>3.0.CO;2-P

[43] Clark, D.E. and Pickett, S.D. (2000) Computational Methods for the Prediction of 'Drug-Likeness'. Drug Discovery Today, 5, 49-58. http://dx.doi.org/10.1016/S1359-6446(99)01451-8

[44] Wildman, S.A. and Crippen, G.M. (1999) Prediction of Physicochemical Parameters by Atomic Contribution. Journal of Chemical Information and Computer Sciences, 39, 868-873. http://dx.doi.org/10.1021/ci9903071

[45] Fukui, K. (1982) Role of Frontier Orbitals in Chemical Reactions. Science, 218, 747-754. http://dx.doi.org/10.1126/science.218.4574.747

[46] Jose, A.P. and Robert, R.S. (1991) Carbene/Anion Complexes. Unusual Structural and Thermochemical Features of .Alpha.-Halocarbanions in the Gas Phase. Journal of the American Chemical Society, 113, 1845-1847.

[47] Parr, R.G., Szentpaly, L.V. and Liu, S. (1999) Electrophilicity Index. Journal of the American Chemical Society, 121, 1922-1924. http://dx.doi.org/10.1021/ja983494x

[48] Chattaraj, P.K., Maiti, B. and Sarkar, U. (2003) Philicity: A Unified Treatment of Chemical Reactivity and Selectivity. The Journal of Physical Chemistry A, 107, 4973-4975. http://dx.doi.org/10.1021/jp034707u

[49] Parr, R.G., Donnelly, R.A., Levy, M. and Palke, W.E. (1978) Electronegativity: The Density Functional Viewpoint. The Journal of Chemical Physics, 68, 3801-3814. http://dx.doi.org/10.1063/1.436185

[50] Parr, R.G. and Pearson, R.G. (1983) Absolute Hardness: Companion Parameter to Absolute Electronegativity. Journal of the American Chemical Society, 105, 7512-7516. http://dx.doi.org/10.1021/ja00364a005

[51] Parr, R.G. and Yang, W. (1989) Density Functional Theory of Atoms and Molecules. Oxford University Press, Oxford. 